\title{
COMBINED MEDICAL TREATMENT OF CHRONIC PANCREATITIS
}

\author{
Larisa Umnova\#, Grigorijs Orlikovs, Jūlija Voicehovska, Vladimirs Voicehovskis, \\ and Eduards Krustiņš
}

Department of Internal Diseases, Rīga Stradiṇš University, Dzirciema iela 16, Rīga, LV-1007, LATVIA; larium@inbox.lv

\# Corresponding author

Communicated by Rafails Rozentāls

\begin{abstract}
The aim of the study was to determine the most effective medical treatment of patients with chronic pancreatitis, by using either pancreatin alone or in combination with proton pump inhibitor (PPI) or PPI and non-steroidal anti-inflammatory drug (NSAID). Patients with chronic pancreatitis, who did not require a surgical treatment, received medical treatment for a one-month period: 20 patients received pancreatin monotherapy; 48 patients were given a combination of pancreatin and PPI; 38 patients were treated with a combination of pancreatin, PPI and NSAID (PNP therapy group). In comparison with other groups, patients in the PNP therapy group showed improvement in body mass index, abdominal pain, bowel movements, chronic pancreatitis severity, as well as their quality of life assessment $(p<0.05)$. The combination of pancreatin, PPI and NSAID was the most effective among those applied in chronic pancreatitis patient treatment. A one-month long course of this therapy was safe and did not cause any significant adverse effects. The combination of pancreatin, PPI and NSAID for treatment of chronic pancreatitis can be recommended, as it is based on pathogenesis of the disease, effective, safe and economically advantageous.
\end{abstract}

Key words: medical treatment of chronic pancreatitis, panccreatic index, quality of life.

\section{INTRODUCTION}

Chronic pancreatitis (CP) is a chronic and permanently progressive non-infectious pancreas inflammation, which is accompanied by destruction and fibrosis of its parenchyma. Even though many etiological factors of $\mathrm{CP}$, such as alcohol consumption, smoking, ductus pancreaticus obstruction, genetic factors and others, are known, pathophysiological mechanisms of the disease are always intrapancreatic activation of digestive enzymes, inflammation and exocrine insufficiency. Recurrent or persistent abdominal pain, as well as exocrine and endocrine insufficiency, are characteristic to $\mathrm{CP}$.

Treatment of CP involves a range of various approaches medical, endoscopic therapy, surgery, etc. Medical therapy is the main method of $\mathrm{CP}$ treatment. In recent years a range of various treatment methods were proposed - use of pancreas enzyme preparations, analgesics, analogues of somatostatin, antidepressants, antioxidants and others. Although the applied preparation spectrum is wide, the outcomes of treatments are often unsatisfactory. The results of clinical studies are contradictory (Brown et al., 1997). The various national illness treatment guidelines recommend a symptomatic medical therapy. In addition, preparation groups are selected step by step depending on the effect achieved (Warshaw et al., 1998; de-Madaria et al., 2013). Presently, widely approved tactics of medical treatment of $\mathrm{CP}$ are not yet developed and discussion of effective therapy persists.

Pancreas injury progression in case of $\mathrm{CP}$ is related to various factors - activation of digestive enzymes in the pancreas (Salija et al., 1999), activation of inflammatory cells (Grady et al., 1997), reactive oxygen species, COX-2 production (Song et al., 2002) and others. 95\% of CP patients suffer from abdominal pain, the cause of which in case of $\mathrm{CP}$ is increase of pressure in parenchymatous tissue of pancreas and its ducts; inflammation; compression of surrounding nerves; ischemia of tissues and infiltration of the organ's nerves with immune cells (Slaff et al., 1984; di Mola et al., 2008).

Presently, one of the most popular CP medical treatment methods is oral use of pancreas enzymes, which affect cholecystokinin (CCK) only, reduce pancreas activity, provide analgesic effect and substitute exocrine function. The described method does not reduce secretine effects - production of pancreas bicarbonates and water. In theory, reduction of secretine effects can be achieved by inhibition of ATF-ases, which are linked to proton pumps in pancreas duct cells. A recent study confirmed the existence of proton 


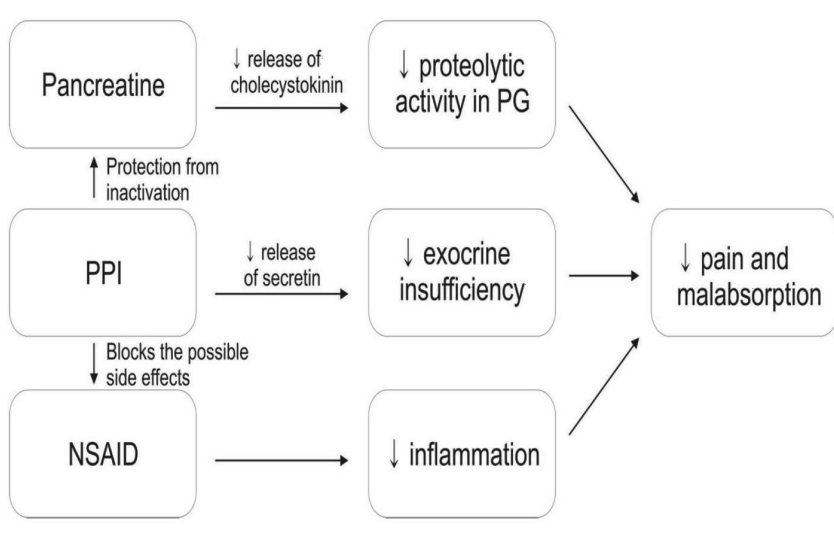

Fig. 1. Pattern of PNP therapy of chronic pancreatitis.

pumps in pancreas duct cells of rats (Novak et al., 2011). The study successfully showed the ability of omeprazole to reduce secretine induced pancreas duct cell secretion by up to $86 \%$. The non-steroidal anti-inflammatory drug (NSAID) in case of $\mathrm{CP}$ is usually used to reduce abdominal pain (Warshaw et al., 1998; Frulloni et al., 2010; de-Madaria et al., 2013).

The authors of the present study elaborated a protocol for medical treatment of CP, named PNP therapy. This therapy utilises a combination of pancreatin, NSAID and proton pump inhibitor (PPI) (Fig. 1). Pancreatin is an animal pancreas extract preparation, the use of which is aimed at reduction of CCK secretion and, consequently, at reduction of secretion of trypsinogen and other pancreas enzymes, as well as supplementation of the deficient pancreas digestive enzymes into duodenum. According to the literature, pancreatin has an analgesic effect (Isaksson and Ihse, 1983; Slaff et al., 1984). NSAID provides analgesic and anti-inflammatory effects. The aim of PPI is to block the secretion of gastric $\mathrm{HCl}$, increase the level of $\mathrm{pH}$ in stomach and duodenum, as well as reduce gastric and duodenum content volume. An increased level of $\mathrm{pH}$ in duodenum causes CCK and reduction of pancreas enzyme secretion and reduction of pancreas parenchyma autolysis. Due to a reduced duodenum volume content and increased $\mathrm{pH}$, secretine production is also decreased, which, in turn, causes a decline of bicarbonate and water production in pancreas ducts. As a result of these processes, pressure in pancreas ducts and tissue autolysis are reduced, which leads to reduction of abdominal pain. PPI also protects the pancreatin from inactivation due to $\mathrm{HCl}$ effects and protects gastrointestinal mucosa from possible NSAID-induced damage.

Evidence suggests that when effects occur on the three main pathogenetic mechanisms of $\mathrm{CP}$ - increased pancreas activity, inflammation and exocrine insufficiency - it is possible to achieve a better CP clinical treatment effect. The purpose of the given study is to determine the most effective medical therapy of CP among pancreatin monotherapy, pancreatin and PPI combined therapy, as well as combined pancreatin, PPI and NSAID therapy.

\section{MATERALS AND METHODS}

The study was conducted in the Centre of Gastroenterology of Pauls Stradiņš Clinical University Hospital between 2007 and 2013. Permission was received from the Ethics Committee of Rīga Stradinšs University and corresponded to EU Directive 2001/20/EC on good clinical practice in clinical trials (Anonymous, 2001) and WMA Declaration of Helsinki (Anonymous, 1964). One hundred and six patients with confirmed diagnosis of CP according to MANNHEIM criteria (Schneider et al., 2007) were investigated in the prospective controlled randomised study. The patients involved did not require surgical or endoscopic treatment. The age of patients, of both sexes, was between 20 and 76 years. Exclusion criteria were as follows: malignant diseases, stomach and duodenum ulcer, severe liver and kidney diseases, acute cerebral and myocardial infarction, significant heart failure, as well as mental diseases. Before and after onemonth medical treatment, all patients had their body mass index (BMI) assessed. Clinical blood analysis was also conducted: blood hemoglobin, RBC (red blood cells) and WBC (white blood cells) count, erythrocyte sedimentation rate (ESR) (standard methods). Blood biochemical analysis included glucose, ASAT, ALAT, $\alpha$-amylase, urea (standard methods). Other completed tests were fecal microscopy (steatorrhea, Drummey et al., 1961), benzidine (fecal occult blood), and fecal elastase-1 (ELISA polyclonal antibody method). In addition, abdominal ultrasonoscopy and assessment of quality of life according to EORTC QLQ-C30 and QLQ-PAN26 questionnaires were carried out. Before treatment all patients had fibrogastroscopy. During treatment, patients made daily notes of abdominal pain, bowel movements and appetite loss, based on specially designed criteria. To assess abdominal pain, a standard $10 \mathrm{~cm}$ visual analogue scale (VAS) was used. Modified results were used in analysis, which were classified as mild, moderate and severe pain. Criteria for abdominal pain, bowel movements and appetite loss assessment are given in Table 1. Summed counts of the above symptoms were determined for the first and the last five days of treatment.

Table 1

CRITERIA FOR ABDOMINAL PAIN, BOWEL MOVEMENTS AND APPETITE LOSS ASSESSMENT (PATIENT DIARY DATA)

\begin{tabular}{|c|c|}
\hline Symptom & Points \\
\hline \multicolumn{2}{|l|}{ Abdominal pain (modified visual analogue scale): } \\
\hline - $\quad$ severe pain ( $8-10$ points by VAS $)$ & 3 \\
\hline moderate pain (4-7 points by VAS) & 2 \\
\hline mild ( $1-3$ points by VAS) & 1 \\
\hline no pain & 0 \\
\hline \multicolumn{2}{|l|}{ Bowel movements: } \\
\hline - $\quad$ diarrhea & 2 \\
\hline constipation & 1 \\
\hline normal & 0 \\
\hline \multicolumn{2}{|l|}{ Loss of appetite: } \\
\hline - $\quad$ yes & 1 \\
\hline no & 0 \\
\hline
\end{tabular}


CP CLINICAL COURSE SEVERITY ASSESSMENT CRITERIA CLINICAL PANCREATIC INDEX (CPI)

\begin{tabular}{|c|c|}
\hline Criterion & Points \\
\hline $\begin{array}{l}\text { Number of surgical procedures due } \\
\text { to } \mathrm{CP} \text { complications in anamnesis }\end{array}$ & $\begin{array}{l}\text { no }-0 ; \text { one }-1 ; \text { two }-2 ; \text { three and } \\
\text { more }-3\end{array}$ \\
\hline Efficiency of outpatient treatment & effective -0 ; ineffective- 2 \\
\hline $\begin{array}{l}\text { Number of hospitalizations due to } \\
\mathrm{CP} \text { in anamnesis }\end{array}$ & $\begin{array}{l}\text { no }-0 ; \text { one }-1 ; \text { two }-2 ; \text { three and } \\
\text { more }-3\end{array}$ \\
\hline Loss of weight (kg) & $\begin{array}{l}0 \mathrm{~kg}-0 ; \text { less than } 3 \mathrm{~kg}-1 ; 3-5 \mathrm{~kg} \\
-2,5 \mathrm{~kg}-3\end{array}$ \\
\hline Severity of pain VAS & $\begin{array}{l}\text { no pain }-0, \text { mild }-1 ; \text { moderate }-2 \text {; } \\
\text { severe }-3\end{array}$ \\
\hline Degree of steatorrhea & $\begin{array}{l}0 \text { or }+-0 ;++-1 ;+++-2 ;++++ \\
\text { and more }-3\end{array}$ \\
\hline Number of daily defecations & $\begin{array}{l}\text { no }-0 ; \text { one }-1 ; \text { two }-2 ; \text { three and } \\
\text { more }-3\end{array}$ \\
\hline $\begin{array}{l}\text { Other dyspeptic complaints (abdom- } \\
\text { inal bloating, borborygmus, nausea, } \\
\text { postprandial abdominal discomfort) }\end{array}$ & $\begin{array}{l}\text { no }-0 ; \text { one }-1 ; \text { two }-2 ; \text { three and } \\
\text { more }-3\end{array}$ \\
\hline Glucose tolerance & $\begin{array}{l}\text { Normal - } 0 \text {, impaired }-1 \text {, diabetes } \\
\text { mellitus }-2\end{array}$ \\
\hline
\end{tabular}

The clinical course severity of $\mathrm{CP}$ was assessed using a quantitative indicator - clinical pancreatic index (CPI). CPI is based on CP progression criteria. CPI involves assessment and summarisation of $\mathrm{CP}$ severity indicators such as number of $\mathrm{CP}$ related surgical operations in anamnesis, number of hospitalisations due to $\mathrm{CP}$, weight loss, abdominal pain and steatorrhea severity, daily bowel movements, other dyspeptic complaints, and glucose intolerance. A higher CPI is associated with a more severe clinical course $\mathrm{CP}$. The maximum CPI score is 25 . Depending on the score, severity of CP clinical course is assessed as follows: mild - 6-8 points, moderate $-9-15$, severe $-16-25$ points (Table 2).

For assessment of quantitative pancreas structural changes, a visual pancreatic index (VPI) was used (Orlikovs et al., 2007). VPI is based on six pancreas visual parameter groups: pancreas head size, pancreas echostructure, calcinates, ductus pancreaticus diameter, pseudocysts, and other. Every pancreas visual parameter was classified depending on its severity, using a 0 to 3 point system. The total VPI is estimated as the sum of all parameter points. Changes in CP were classified depending on severity - total score: $0-3$ points - CP diagnosis is doubtful; 4-8 points mild changes; $9-14$ points - moderate changes; $15-21-$ severe changes (see Table 3). Abdominal ultrasonography data were used for calculation of VPI; however, for VPI calculation other sources can be used, such as endoscopic ultrasonography, abdominal computed tomography, and endoscopic retrograde cholangeopancreatography.

The patients were divided in three groups, depending on type of therapy. Division of patients and types of therapy
CRITERIA OF PANCREAS PARENCHYMA STRUCTURE CHANGES IN CASE OF CP - VISUAL PANCREATIC INDEX (VPI)

\begin{tabular}{|c|c|c|}
\hline Criterion & $\begin{array}{c}\text { Degree of } \\
\text { expressiveness }\end{array}$ & Points \\
\hline \multirow[t]{4}{*}{ The size of caput pancreatic } & $3.0 \mathrm{~cm}$ & 0 \\
\hline & $>3.0 \mathrm{~cm}$ & 1 \\
\hline & $2.5-2.9 \mathrm{~cm}$ & 2 \\
\hline & $<2.5 \mathrm{~cm}$ & 3 \\
\hline \multirow[t]{4}{*}{ The echotexture of pancreas } & homogenic & 0 \\
\hline & medium granular & 1 \\
\hline & local granular & 2 \\
\hline & diffuse granular & 3 \\
\hline \multirow[t]{4}{*}{ Calcinates } & no calcinates & 0 \\
\hline & local small & 1 \\
\hline & multiple 3-4 mm * & 2 \\
\hline & diffuse & 3 \\
\hline \multirow{4}{*}{$\begin{array}{l}\text { Maximal diameter of ductus } \\
\text { pancreaticus }\end{array}$} & $>3 \mathrm{~mm}$ & 0 \\
\hline & $3-4 \mathrm{~mm}$ & 1 \\
\hline & $4.1-5.0 \mathrm{~cm}$ & 2 \\
\hline & $<5 \mathrm{~mm}$ & 3 \\
\hline \multirow[t]{4}{*}{ Pseudocysts } & no pseudocysts & 0 \\
\hline & $<3 \mathrm{~cm} *$ & 1 \\
\hline & $3.1-5 \mathrm{~cm} \cdot$ & 2 \\
\hline & $>5 \mathrm{~cm} \cdot$ & 3 \\
\hline \multirow[t]{3}{*}{ Other changes } & no changes & 0 \\
\hline & irregular contours of pancreas & 1 \\
\hline & peripancreatic fibrosis & 2 \\
\hline
\end{tabular}

Table 4

DIVISION OF PATIENTS AND TYPES OF THERAPY

\begin{tabular}{l|l|c}
\hline Group & \multicolumn{1}{|c}{ Type of medical treatment } & $\begin{array}{c}\text { Number of } \\
\text { patients }\end{array}$ \\
\hline P & Pangrol 25000 - 1 capsule t.i.d. & 20 \\
PP & Pangrol 25000 - 1 capsule t.i.d. & 48 \\
& Omeprazol 20 mg pa 1 capsule b.i.d. & 38 \\
PNP $\quad$ Pangrol 25000 - 1 capsule t.i.d. & \\
& Omeprazol 20 mg - 1 capsule b.i.d. & \\
& Airtal (Aceclofenac) 100 mg -1 tab. b.i.d. & 106
\end{tabular}

are described in Table 4. The medical treatment extended for one month.

Pangrol 25000 consists of enteric coated microspheres of pancreatin. One Pangrol 25000 capsule lipase activity corresponds to 25000 EPU (European Pharmacopoeia units), amylase activity not less than 22500 EPU and protease activity not less than 1250 EPU. The manufacturer of Pangrol 25000 is Berlin-Chemie AG (Menarini Group). Every Omeprazols capsule contains $20 \mathrm{mg}$ of omeprazole in a hard gelatine capsule. Omeprazols produced by Olainfarm JSC was used in the research. Airtal is a coated tablet that con- 
tains $100 \mathrm{mg}$ of aceclofenac, manufacturer - Gedeon Richter.

The statistical processing of research results was done using IBM SPSS 20.0. The Wilcoxon Signed Ranks Test and Mann-Whitney Test were used. ANCOVA (Analysis of Covariance) was used for multi-factor analysis and the Post-hoc Sidac was used to detrermine significant differences between groups. A $p<0.05$ was considered as statistically significant.

\section{RESULTS}

The average age of patients (SD) was 53.33 (12.42) years. Before the study alcohol was regularly consumed by 63 patients $(59.4 \%)$, and 54 patients were smokers (50.9\%). Average disease duration was: median $=36 ; \mathrm{IQR}=78$ months.

Patients in the pancreatin monotherapy group experienced statistically significant improvement regarding abdominal pain, appetite loss, WBC count, blood $\alpha$-amylase, ASAT, ALAT and urea (see Table 5).

Patients in the combined pancreatin and PPI therapy group had significant improvement of abdominal pain, bowel movements, steatorrhea, WBC count, ESR, blood $\alpha$-amylase, ALAT, ASAT and CPI (see Table 6).

Patients in the combined pancreatin, PPI and NSAID therapy group (PNP therapy) after treatment experienced signif-

Table 5

INDICANT CHANGES IN THE PANCREATIN MONOTHERAPY GROUP (GROUP P)

\begin{tabular}{|c|c|c|c|}
\hline Indicant & $\begin{array}{c}\text { Mean value before } \\
\text { treatment plus } \\
\text { standart error }\end{array}$ & $\begin{array}{c}\text { Mean value after } \\
\text { treatment plus } \\
\text { standart error }\end{array}$ & $\begin{array}{c}\text { Wilcoxon } \\
\text { test, } \\
p \text { value }\end{array}$ \\
\hline BMI $\left(\mathrm{kg} / \mathrm{m}^{2}\right)$ & $25.24 \pm 0.99$ & $26.43 \pm 1.13$ & 1.000 \\
\hline Abdominal pain* & $9.21 \pm 0.96$ & $6.11 \pm 0.84$ & 0.008 \\
\hline $\begin{array}{l}\text { Abnormal bowel } \\
\text { movements* }\end{array}$ & $3.35 \pm 0.84$ & $2.19 \pm 0.67$ & 0.137 \\
\hline Loss of appetite* & $2.33 \pm 0.52$ & $0.93 \pm 0.41$ & 0.035 \\
\hline Steatorrhea & $1.21 \pm 0.33$ & $1.00 \pm 0.21$ & 0.206 \\
\hline Fecal elastase $1(\stackrel{\mathrm{g} g}{\mathrm{~g}} / \mathrm{g})$ & $179.20 \pm 42.60$ & $219.92 \pm 44.70$ & 0.327 \\
\hline WBC count $\left(10^{9} / \mathrm{L}\right)$ & $9588.00 \pm 642.00$ & $7475.00 \pm 304.00$ & 0.003 \\
\hline $\mathrm{Hb}(\mathrm{g} / \mathrm{L})$ & $138.53 \pm 5.40$ & $135.23 \pm 4.18$ & 0.861 \\
\hline RBC count $\left(10^{12} / \mathrm{L}\right)$ & $4.44 \pm 0.18$ & $4.44 \pm 0.12$ & 0.625 \\
\hline ESR (mm/h) & $16.00 \pm 3.23$ & $15.50 \pm 3.09$ & 0.310 \\
\hline $\begin{array}{l}\text { Blood } \alpha \text {-amylase } \\
(\mathrm{U} / \mathrm{L})\end{array}$ & $329.78 \pm 52.00$ & $135.92 \pm 26.00$ & 0.003 \\
\hline ALAT (U/L) & $70.00 \pm 12.20$ & $42.64 \pm 5.64$ & 0.005 \\
\hline ASAT (U/L) & $87.25 \pm 21.30$ & $46.64 \pm 7.14$ & 0.004 \\
\hline Urea (moll/1) & $6.70 \pm 0.51$ & $5.50 \pm 0.39$ & 0.041 \\
\hline Total CPI* & $10.05 \pm 1.02$ & $7.88 \pm 0.81$ & 0.068 \\
\hline Total VPI* & $5.60 \pm 1.19$ & $4.67 \pm 1.07$ & 0.581 \\
\hline
\end{tabular}

* - sum of points; BMI - body mass index; WBC, white blood cells; RBC, red blood cells; ESR - erythrocyte sedimentation rate; ALAT - alanine aminotransferase; ASAT - aspartate aminotransferase; CPI - clinical pancreatic index; VPI - visual pancreatic index. icant improvements in BMI, abdominal pain, bowel movements, appetite, steatorrhea, blood $\alpha$-amylase, WBC count, ESR, CPI and VPI (see Table 7).

CP therapy safety indicators, such as RBC count and haemoglobin, remained constant after treatment in all groups of

Table 6

INDICANT CHANGES IN THE PANCREATIN AND PPI COMBINED THERAPY GROUP (GROUP PP)

\begin{tabular}{l|c|c|c}
\hline \multicolumn{1}{c|}{ Indicant } & $\begin{array}{c}\text { Mean value before } \\
\text { treatment plus } \\
\text { standart error }\end{array}$ & $\begin{array}{c}\text { Mean value after } \\
\text { treatment plus } \\
\text { standart error }\end{array}$ & $\begin{array}{c}\text { Wilcoxon } \\
\text { test, } \\
p \text { value }\end{array}$ \\
\hline BMI $\left(\mathrm{kg} / \mathrm{m}^{2}\right)$ & $24.99 \pm 0.91$ & $25.00 \pm 0.89$ & 0.671 \\
Abdominal pain* & $8.62 \pm 0.83$ & $5.62 \pm 0.84$ & 0.006 \\
Abnormal bowel & $3.10 \pm 0.82$ & $0.95 \pm 0.36$ & 0.016 \\
movements* & & & \\
Loss of appetite* & $0.95 \pm 0.36$ & $0.57 \pm 0.33$ & 0.270 \\
Steatorrhea* & $1.85 \pm 0.21$ & $0.40 \pm 0.13$ & 0.001 \\
Fecal elastase $1(\mu \mathrm{g} / \mathrm{g})$ & $240.93 \pm 54.40$ & $236.93 \pm 44.70$ & 0.286 \\
WBC count $\left(10^{9} / \mathrm{L}\right)$ & $8779.00 \pm 590.00$ & $7435.00 \pm 494.00$ & 0.009 \\
Hb $(\mathrm{g} / \mathrm{L})$ & $138.65 \pm 3.00$ & $137.10 \pm 2.00$ & 0.837 \\
RBC count $\left(10^{12} / \mathrm{L}\right)$ & $4.66 \pm 0.10$ & $4.64 \pm 0.09$ & 0.324 \\
ESR $(\mathrm{mm} / \mathrm{h})$ & $17.85 \pm 2.56$ & $13.65 \pm 1.87$ & 0.021 \\
Blood $\alpha-$ amylase $(\mathrm{U} / \mathrm{L})$ & $127.60 \pm 17.30$ & $83.25 \pm 9.44$ & 0.001 \\
ALAT $(\mathrm{U} / \mathrm{L})$ & $30.45 \pm 4.75$ & $23.47 \pm 2.31$ & 0.025 \\
ASAT $(\mathrm{U} / \mathrm{L})$ & $29.85 \pm 2.93$ & $26.37 \pm 2.39$ & 0.025 \\
Urea $(\mathrm{moll} / \mathrm{l})$ & $6.82 \pm 0.61$ & $6.45 \pm 0.62$ & 0.295 \\
Total CPI* & $12.26 \pm 0.62$ & $5.33 \pm 0.52$ & 0.001 \\
Total VPI* & $2.47 \pm 0.23$ & $2.11 \pm 0.25$ & 0.176
\end{tabular}

For explanations see Table 5.

Table 7

INDICANT CHANGES IN THE PANCREATIN, PPI AND NSAID COMBINED THERAPY GROUP (PNP THERAPY GROUP)

\begin{tabular}{|c|c|c|c|}
\hline Indicant & $\begin{array}{c}\text { Mean value before } \\
\text { treatment plus } \\
\text { standart error }\end{array}$ & $\begin{array}{c}\text { Mean value after } \\
\text { treatment plus } \\
\text { standart error }\end{array}$ & $\begin{array}{c}\text { Wilcoxon } \\
\text { test, } \\
p \text { value }\end{array}$ \\
\hline BMI $\left(\mathrm{kg} / \mathrm{m}^{2}\right)$ & $24.77 \pm 1.03$ & $25.33 \pm 1.05$ & 0.001 \\
\hline Abdominal pain* & $9.78 \pm 0.61$ & $2.19 \pm 0.62$ & 0.001 \\
\hline $\begin{array}{l}\text { Abnormal bowel } \\
\text { movements* }\end{array}$ & $3.87 \pm 0.63$ & $0.53 \pm 0.27$ & 0.001 \\
\hline Loss of appetite* & $2.33 \pm 0.41$ & $0.17 \pm 0.10$ & 0.001 \\
\hline Steatorrhea & $1.73 \pm 0.18$ & $0.31 \pm 0.09$ & 0.001 \\
\hline Fecal elastase $1(\mu \mathrm{g} / \mathrm{g})$ & $206.43 \pm 36.00$ & $283.95 \pm 41.30$ & 0.070 \\
\hline WBC count $\left(10^{9} / \mathrm{L}\right)$ & $10325.00 \pm 776.00$ & $7448.00 \pm 324.00$ & 0.001 \\
\hline $\mathrm{Hb}(\mathrm{g} / \mathrm{L})$ & $146.43 \pm 3.70$ & $141.57 \pm 2.69$ & 0.100 \\
\hline RBC count $\left(10^{12} / \mathrm{L}\right)$ & $4.87 \pm 0.10$ & $4.69 \pm 0.10$ & 0.215 \\
\hline $\operatorname{ESR}(\mathrm{mm} / \mathrm{h})$ & $21.45 \pm 3.65$ & $11.43 \pm 1.88$ & 0.018 \\
\hline $\begin{array}{l}\text { Blood } \alpha \text {-amylase } \\
(\mathrm{U} / \mathrm{L})\end{array}$ & $343.46 \pm 75.90$ & $99.97 \pm 17.60$ & 0.001 \\
\hline ALAT (U/L) & $53.50 \pm 13.60$ & $37.83 \pm 6.50$ & 0.721 \\
\hline ASAT (U/L) & $54.58 \pm 12.00$ & $31.00 \pm 5.00$ & 0.600 \\
\hline Urea $(\mathrm{mmol} / \mathrm{l})$ & $4.91 \pm 0.57$ & $5.45 \pm 0.54$ & 0.500 \\
\hline Total CPI* & $12.00 \pm 0.66$ & $2.87 \pm 0.37$ & 0.001 \\
\hline Total VPI* & $5.28 \pm 0.59$ & $3.70 \pm 0.54$ & 0.001 \\
\hline
\end{tabular}

For explanations see Table 5. 
Table 8

DIFFERENCES OF INDICANT CHANGES AFTER THE TREATMENT BETWEEN STUDY GROUPS

\begin{tabular}{|c|c|c|c|c|}
\hline \multirow[t]{2}{*}{ Indicator } & \multirow{2}{*}{$\begin{array}{c}\text { Three group } \\
\text { comparison } \\
\text { (ANCOVA } \\
\text { test, } \\
p \text { value) } \\
\end{array}$} & \multicolumn{3}{|c|}{$\begin{array}{c}\text { Levels of indicant changes in groups } \\
\text { (ANCOVA Post-hoc Sidac test, } \\
p \text { value) }\end{array}$} \\
\hline & & group $\mathrm{P}$ & group PP & group PNP \\
\hline BMI $\left(\mathrm{kg} / \mathrm{m}^{2}\right)$ & 0.019 & 0.234 & 0.070 & 0.068 \\
\hline Abdominal pain* & 0.001 & 0.389 & 0.001 & 0.001 \\
\hline $\begin{array}{l}\text { Abnormal bowel } \\
\text { movements* }\end{array}$ & 0.020 & 0.033 & 0.006 & 0.628 \\
\hline Loss of appetite* & 0.056 & 0.337 & 0.022 & 0.161 \\
\hline Steatorrhea & 0.001 & 0.003 & 0.001 & 0.526 \\
\hline Fecal elastase $1(\mu \mathrm{g} / \mathrm{g})$ & 0.366 & 0.336 & 0.872 & 0.177 \\
\hline WBC count $\left(10^{9} / \mathrm{L}\right)$ & 0,669 & 0.940 & 0.521 & 0.410 \\
\hline $\mathrm{Hb}(\mathrm{g} / \mathrm{L})$ & 0.629 & 0.575 & 0.339 & 0.648 \\
\hline RBC count $\left(10^{12} / \mathrm{L}\right)$ & 0.770 & 0.512 & 0.510 & 0.988 \\
\hline $\operatorname{ESR}(\mathrm{mm} / \mathrm{h})$ & 0,170 & 0.137 & 0.610 & 0.565 \\
\hline Blood $\alpha$-amylase (U/L) & 0.086 & 0.197 & 0.029 & 0.328 \\
\hline ALAT (U/L) & 0.438 & 0.032 & 0.642 & 0.213 \\
\hline ASAT (U/L) & 0.084 & 0.031 & 0.137 & 0.582 \\
\hline Urea $(\mathrm{mmol} / \mathrm{l})$ & 0.241 & 0.094 & 0.411 & 0.518 \\
\hline Total CPI* & 0.001 & 0.019 & 0.001 & 0.001 \\
\hline Total VPI* & 0.271 & 0.344 & 0.113 & 0.480 \\
\hline
\end{tabular}

For explanations see Table 5.

patients; moreover, they were similar after treatment between groups. In the pancreatin monotherapy group and pancreatin and PPI combined therapy group, ASAT and ALAT levels decreased significantly after treatment, while in the pancreatin, PPI and NSAID combined therapy group they remained unchanged. Urea showed a drop only in the pancreatin monotherapy group; in the other groups urea did not significantly differ. A significant CPI reduction was observed in the pancreatin and PPI combined therapy group and pancreatin, PPI and NSAID combined therapy group $(P<0.001)$; VPI differed significantly only in the pancreatin, PPI and NSAID combined therapy group patients $(P<0.001)$. Significant differences between groups are summarised in Table 8.

According to EORTC QLQ-C30, CP symptom severity declined in all groups $(P<0.05)$ after treatment. EORTC QLQ-C30 global health significantly improved in all study groups $(P<0.05)$, functioning (sum of functioning scale points) improved in the pancreatin and PPI combined therapy group and pancreatin, PPI and NSAID combined therapy group $(P<0.05)$. Sum of points for QLQ-PAN26 significantly increased in all study groups $(P<0.05)$.

Analysis of covariance (ANCOVA) indicated significant differences between groups after the treatment for BMI, abdominal pain, bowel movements, appetite loss, clinical pancreatic index (see Table 8), as well as sum of points for EORTC QLQ-C30 CP symptom severity, global health, functioning and QLQ-PAN26.

\section{DISCUSSION}

A prospective, randomised, controlled study of combined medical therapy of $\mathrm{CP}$ was carried out to determine the most effective treatment of patients with $\mathrm{CP}$ : by using either pancreatin alone or in combination with PPI or PPI and non-steroidal anti-inflammatory drug (NSAID).

Abdominal pain is one of the hallmark symptoms of $\mathrm{CP}$, and in this study $97.2 \%$ patients noted its presence. To evaluate abdominal pain, both the opinion of the patient and the judgment of the treating physician were taken into consideration. Patient's opinion was evaluated according to entries from the diary, by using both the modified visual analogue scale and several questions from the quality of life questionnaires (questions Nr. 9 and 19 of the EORTC QLQ-C30 and questions Nr. 33 and 34 of the QLQ-PAN26).

Several studies about the analgesic effect of the pancreatins have shown conflicting results, but meta-analysis concluded that they are not effective for relieving abdominal pain in case of CP (Brown et al., 1997). This could be explained by the very heterogeneous patient population in terms of both the etiology and the severity of the disease, as well as the pharmaceutical formulation of pancreatin used and the duration of the treatment. Therefore, in our opinion, the results of this meta-analysis remain questionable. It is important to remember the $\mathrm{CP}$ is not a homogenous disease. There are at least six types depending on the etiology, and the clinical course is highly variable, ranging from intermittent to persistent abdominal pain or development of pancreas burnout syndrome. The causes of abdominal pain also can be quite different - large duct disease is more frequently associated with chronic pain that resists treatment, in comparison to small duct disease, which often has a much better response. This study included $84.5 \%$ patients with small duct disease, which might explain the increased effectiveness of pancreatin.

Four studies that evaluated the use of enteric coated pancreatin showed an analgesic effect that was close to that of the placebo (Halgreen et al., 1986; Larvin et al., 1991; Mössner et al., 1992; Malesci et al., 1995). That might be explained by the fact that the enzymes in these studies were released outside duodenum, and therefore they were not able to suppress the secretion of cholecystokinin. Interestingly, in all studies showing lack of effectiveness of pancreatin for treatment of abdominal pain in $\mathrm{CP}$, there was a paradoxically high placebo effect - up to $40 \%$ (Halgreen et al., 1986; Mössner et al., 1989; Mössner et al., 1992; Malesci et al., 1995), despite the fact that frequently such pain is treatment resistant. Several explanations have been given for the exceptionally high placebo effect. Firstly, most of the studies had a crossover design, which lacked a wash-out period, thereby artificially increasing the placebo effect (Halgreen et al., 1986; Mössner et al., 1992; Malesci et al., 1995). Secondly, three of four studies that showed a lack of effectiveness of the pancreatin for the treatment of abdominal pain in $\mathrm{CP}$ had a short treatment duration from one to two weeks, which may be insufficient to 
achieve the desired effect. Thirdly, the above cited studies used high doses of pancreatin, which exceeded the recommended dosage for the treatment of steatorrhea. The patients in one study received $10000 \mathrm{IU}$ of proteases/day (Mössner et al., 1992) whereas the patients in our study received only $3750 \mathrm{IU} /$ day. It has been shown that high doses of proteases can stimulate rather than decrease exocrine secretion of pancreas, thereby promoting secretion of cholecystokinin and in such a way increasing pain (Mössner et al., 1989; Mössner et al., 1991). However, a recent meta-analysis study of abdominal pain due to CP concluded that the placebo effect on abdominal pain is lower and can be observed in $20 \%$ of cases (Capurso et al., 2012). In previous studies this possibly hindered study of the effect of enteric coated pancreatin in decreasing abdominal pain. In our study a moderate $34 \%(p<0.05)$ analgesic effect of pancreatin was observed.

The existing guidelines for treatment of $\mathrm{CP}$ recommend the use of PPIs to increase the effect of pancreatin only in cases of steatorrhea (Warshaw et al., 1998; Frulloni et al., 2010; de-Madaria et al., 2013). However, when pathogenesis of $\mathrm{CP}$ is taken into consideration, PPIs can be useful not only in decreasing secretion of gastric acid but also in decreasing exocrine secretion of pancreas, as PPIs can block the ATP-ases of pancreas duct cells (Novak et al., 2011). As a result, a decline of bicarbonate and water production in pancreas ducts can be expected with subsequent reduction of abdominal pain. In our study the combination of PPI and pancreatin was more effective in decreasing abdominal pain, impaired bowel movements and steatorrhea and for improving quality of life, when compared to pancreatin monotherapy. Thereby our study shows that, in addition to previously published guidelines, PPIs can have a wider application for treatment of CP.

Most of the national guidelines include NSAIDs as a treatment for CP (Warshaw et al., 1998; Frulloni et al., 2010; de-Madaria et al., 2013). One study showed that sulindac was not only an effective analgesic for $\mathrm{CP}$, but also decreased both the fibrosis of the pancreas and the parenchymal infiltration with immune cells (Bai et al., 2012). As any other drug, NSAIDs have risk of adverse effects. The most serious among those are gastrointestinal and cardiovascular events, but the frequency of such adverse effects in case of $\mathrm{CP}$ has not been studied. The common concerns about conventional NSAIDs partially stem from the frequent use of these medications without any kind of gastric protection, and from the fact that the prescription guidelines are frequently ignored. Studies have shown that the selective COX-2 inhibitors are much less toxic and that by adding a PPI the risk of gastrointestinal complications is greatly reduced. A combination of selective NSAID and a PPI is also economically advantageous, as the PPIs are relatively cheap but their beneficial impact is great. As only $1 / 3$ of patients who are using NSAIDs are being prescribed an appropriate gastric protection and only $44 \%$ of these patients are adhering to such recommendations (Gigante and Tagarro, 2012; Jonasson et al., 2013), fixed dose combinations of a NSAID and a PPI are becoming increasingly popular. Cardiovascular risks of NSAIDs have been evaluated in meta-analysis of thirty one randomised controlled trials dedicated to seven NSAIDs: naproxen, ibuprofen, diclofenac, celecoxib, etoricoxib, rofecoxib and lumiracoxib (Trelle et al., 2011). The majority of the mentioned studies recommended an over three-month long therapy for patients with rheumatoid arthritis and osteoarthritis. These patients may have higher cardiovascular risk due to limited physical activity. In case of many illnesses the benefit of applying NSAIDs exceeds the risks of adverse effects, under condition that NSAID is used in small doses for a short period of time. In the given study NSAID was represented by aceclofenac, which is not a selective COX-2 inhibitor, however aceclofenac inhibits COX-2 more potently than COX-1. Therefore, it is much safer than many other NSAIDs in terms of gastrointestinal adverse effects. Moreover, the aceclofenac dosage was set according to manufacturer recommendations (30 days), which can be considered a short-term therapy. Strict compliance with NSAID therapy contraindications such as gastric or duodenum ulcer, gastrointestinal bleeding in anamnesis, severe liver and kidney diseases, acute cerebral or myocardial infarction and significant heart failure, which served as exclusion criteria in the given study, allowed to avoid the possible side effects of aceclofenac. In the given study, in order to assess the safety of aceclofenac, before and after treatment, several indicators were used: hemoglobin level, RBC count, fecal occult blood, ALAT, ASAT and urea. The analysis of study results showed that after therapy the mentioned indicants did not worsen in patients who received aceclofenac as a part of pancreatin, PPI and NSAID combined therapy. There were no gastrointestial and cardiovascular events during the study in the pancreatin, PPI and NSAID combined therapy group but one patient from the pancreatin monotherapy group had nonfatal stoke.

The results of this study showed that for reduction of abdominal pain and impaired bowel movements in patients with CP, PNP therapy is more effective than treatment with pancreatin alone or than treatment with a combination of pancreatin and a PPI. In addition, such treatment also increases the BMI and improves the clinical course of the disease and the quality of life. A one-month long course of PNP therapy in patients with CP was safe and did not cause any significant side effects. Such treatment of CP is rational, as it is based on pathogenesis, effectivity, safety and cost.

\section{ACKNOWLEDGEMENTS}

This study was supported by ESF project Nr. 2009/0147/1DP/1.1.2.1.2/09/IPIA/VIAA/009.

\section{REFERENCES}

Anonymous (2001). Directive 2001/20/EC of the European Parliament and of the Council of 4 April 2001 on the approximation of the laws, regulations and administrative provisions of the Member States relating to the implementation of Good Clinical Practice in the conduct of clinical trials on medicinal products for human use. OJ EC, L121, 34-41. 
http://ec.europa.eu/health/files/eudralex/vol-1/dir_2001_20/dir_2001_20 _en.pdf (accessed 12 September 2014).

Anonymous (1964). WMA Declaration of Helsinki - Ethical Principles for Medical Research Involving Human Subjects Adopted by the $18^{\text {th }}$ WMA General Assembly, Helsinki, Finland, June 1964 and amended by the: $29^{\text {th }}$ WMA General Assembly, Tokyo, Japan, October $1975 ; 35^{\text {th }}$ WMA General Assembly, Venice, Italy, October 1983; $41^{\text {st }}$ WMA General Assembly, Hong Kong, September 1989; $64^{\text {th }}$ WMA General Assembly, Fortaleza, Brazil, October 2013

http://www.wma.net/en/30publications/10policies/b3/ (accessed 12 September 2014).

Bai, H., Chen, X., Zhang, L., Dou, X. (2012). The effect of sulindac, a non-steroidal anti-inflammatory drug, attenuates inflammation and fibrosis in a mouse model of chronic pancreatitis. BMC Gastroenterol., 24 (12), 115 .

Brown, A., Hughes, M., Tenner, S., Banks, P. (1997). Does pancreatic enzyme supplementation reduce pain in patients with chronic pancreatitis: A meta-analysis. Amer. J. Gastroenterol., 92 (11), 2032-2035.

Capurso, G., Cocomello, L., Benedetto, U., Cammà, C., Delle Fave, G.. (2012). Meta-analysis: The placebo rate of abdominal pain remission in clinical trials of chronic pancreatitis. Pancreas, 41 (7),1125-1131.

Drummey, G., Benson, J., Jones, C. (1961). Microscopical examination of the stool for steatorrhea. New Engl. J. Med., 264, 85-87.

Frulloni, L., Falconi, M., Gabbrielli, A., et al. (2010). Italian consensus guidelines for chronic pancreatitis. Dig. Liver. Dis., 42 (6), S381-S406.

Gigante, A., Tagarro, I. (2012). Non-steroidal anti-inflammatory drugs and gastroprotection with proton pump inhibitors: A focus on ketoprofen/ omeprazole. Clin. Drug Investig., 32 (4), 221-233.

Grady, T., Liang, P., Ernst, S., Logsdon, C. (1997). Chemokine gene expression in rat pancreatic acinar cells is an early event associated with acute pancreatitis. Gastroenterology, 113, 1966-1975.

Halgreen, H., Pedersen, N., Worning, H. (1986). Symptomatic effect of pancreatic enzyme therapy in patients with chronic pancreatitis. Scand. $J$. Gastroenterol., 21 (1), 104-8.

Isaksson, G., Ihse, I. (1983). Pain reduction by an oral pancreatic enzyme preparation in chronic pancreatitis. Dig. Dis. Sci., 28 (2), 97-102.

Jonasson, C., Hatlebakk, J., Lundell, L., Kouri, J. P., Andersen, M., Granath, F. (2013). Association between adherence to concomitant proton pump inhibitor therapy in current NSAID users and upper gastrointestinal complications. Eur. J. Gastroenterol. Hepatol., 25 (5), 531-538.

Larvin, M., McMahon, M., Thomas, W., Puntis, M. C. A. (1991). Creon (enteric coated pancreatin microspheres) for the treatment of pain in chronic pancreatitis: A double-blind randomized placebo-controlled crossover study. Gastroenterology, 100, A283.

Lin, Y., Tamakoshi, A., Matsuno, S., Takeda, K., Hayakawa, T., Kitagawa, M., Naruse, S., Kawamura, T., Wakai, K., Aoki, R., Kojima, M., Ohno, Y. (2000). Nationwide epidemiological survey of chronic pancreatitis in Japan. J. Gastroenterol., 35 (2), 136-141.

de-Madaria, E., Abad-González, A., Aparicio, J., Aparisi, L., Boadas, J., Boix, E., de-Las-Heras, G., Domínguez-Muñoz, E., Farré, A.,
Fernández-Cruz, L., Gómez, L., Iglesias-García, J., García-Malpartida, K., Guarner, L., Lariño-Noia, J., Lluís, F., López, A., Molero, X., Moreno-Pérez, O., Navarro, S., Palazón, J. M., Pérez-Mateo, M., Sabater, L.,Sastre, Y., Vaquero, E. C., Martínez, J. (2013). The Spanish Pancreatic Club's recommendations for the diagnosis and treatment of chronic pancreatitis: Part 2 (treatment). Pancreatology, 13 (1), 18-28.

Malesci, A., Gaia, E., Fioretta, A., Bocchia, P., Ciravegna, G., Cantor, P., Vantini, I. (1995). No effect of long-term treatment with pancreatic extract on recurrent abdominal pain in patients with chronic pancreatitis. Scand. J. Gastroenterol., 30 (4), 392-398.

di Mola, F. F., di Sebastiano, P. (2008). Pain mechanisms in chronic pancreatitis. In: Beger, H. G., Buchler, M., Kozarek, R., Lerch, M., Neoptolemos, J., Warshaw, A., Whitcomb, D., Shiratori, K. (eds). The Pancreas: An Integrated Textbook of Basic Science, Medicine, and Surgery, 2nd edn. (pp. 375-563). Oxford: Wiley-Blackwell.

Mössner, J., Secknus, R., Meyer, J., Niederau, C., Adler, G. (1992). Treatment of pain with pancreatic extracts in chronic pancreatitis: Results of a prospective placebo-controlled multicenter trial. Digestion, 53 (1-2), 54-66.

Mössner, J., Stange, J., Ewald, M., Kestel, W., Fischbach, W. (1991). Influence of exogenous application of pancreatic extracts on endogenous pancreatic enzyme secretion. Pancreas, 6 (6), 637-44.

Mössner, J., Wresky, H.P., Kestel, W., Zeeh, J., Regner, U., Fischbach, W. (1989). Influence of treatment with pancreatic extracts on pancreatic enzyme secretion. Gut, 30 (8), 1143-1149.

Novak, I., Wang, J., Henriksen, K., Haanes, K. A., Krabbe, S., Nitschke, R., Hede, S. E. (2011). Pancreatic bicarbonate secretion involves two proton pumps. J. Biol. Chem., 286 (1), 280-9.

Orḷikovs, G., Pḷaviņa, I., Selezņovs, J., Pokrotnieks, J., Karpovs, J., Voicehovska, J. (2007). Pancreatic index: A new approach to chronic pancreatitis estimation. Proc. Latvian Acad. Sci., Section B, 61 (1/2), 43-46.

Schneider, A., Löhr, J. M., Singer, M. V. (2007). The M-ANNHEIM classification of chronic pancreatitis: Introduction of a unifying classification system based on a review of previous classifications of the disease. $J$. Gastroenterol., 42 (2), 101-119.

Slaff, J., Jacobson, D., Tillman, C., Curington, C., Toskes, P. (1984). Protease-specific suppression of pancreatic exocrine secretion. Gastroenterology, 87, 44-52.

Song, A., Bhagat, L., Singh, V., et al. (2002). Inhibition of cyclooxygenase-2 ameliorates the severity of pancreatitis and associated lung injury. Amer. J. Physiol., 283, G1166-G1174.

Trelle, S., Reichenbach, S., Wandel, S., Hildebrand, P., Tschannen, B., Villiger, P. M., Egger, M., Jüni, P. (2011) Cardiovascular safety of non-steroidal anti-inflammatory drugs: Network meta-analysis. BMJ (British Medical Journal), 342, c7086.

Warshaw, A., Banks, P., Fernández-Del Castillo, C. (1998). AGA technical review: Treatment of pain in chronic pancreatitis. Gastroenterology, 115 (3), 765-76.

Yadav, D., Timmons, L., Benson, J., Dierkhising, R. A., Chari, S. T. (2011). Incidence, prevalence, and survival of chronic pancreatitis: A population-based study. Amer. J. Gastroenterol., 106 (12), 2192-2199.

Received 20 September 2013

\section{HRONISKA PANKREATĪTA KOMBINĒTĀ MEDIKAMENTOZĀ TERAPIJA}

Darba mērḳis bija, lietojot pankreatīnu monoterapijā un kombinācijā ar protonu sūkṇa inhibitoru, kā arī kombinējot pankreatīnu, protonu sūkṇa inhibitoru un nesteroīdo pretiekaisuma līdzekli (NSPL) pacientiem ar hronisku pankreatītu (HP), noskaidrot efektīvāko no lietotām terapijām. Pacienti ar HP, kuriem nebija nepieciešama ķirurğiskā un endoskopiskā ārstēšana, saņēma mēnesi ilgu medikamentozo terapiju: 20 pacienti saṇēma pankreatīna monoterapiju (P grupa); 48 pacienti saṇēma pankreatīna un protonu sūkṇa inhibitora kombināciju (PP grupa); 38 pacienti saṇēma pankreatīna, protonu sūkṇa inhibitora un NSPL kombināciju (PNP grupa). K̦ermeṇa masas indekss, abdominālās sāpes, vēdera izeja, slimīibas klīniskā gaita un lielākā dą̣a dzīves kvalitātes rādītāju uzlabojusies PNP grupā izteiktāk, salīdzinot ar P un PP grupu $(P<0,05)$. Pacientiem ar hronisku pankreatîtu mēnesi ilga terapija ar pankreatīna, protonu sūkna inhibitora un nesteroīdā pretiekaisuma līdzekḷa kombināciju ir droša un neizraisa nopietnas blakusparādības. Pankreatīna, protonu sūkṇa inhibitora un nesteroīdā pretiekaisuma līdzekḷa kombinācija hroniska pankreatīta ārstēšanai ir racionāla, jo tā ir patoğenētiski pamatota, efektīva, droša un ekonomiski lietderīga. 